\title{
YALE
}

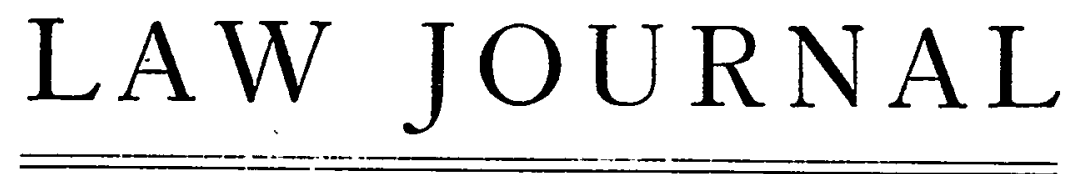

\begin{tabular}{lll}
\hline Vol. IX. & MAY, 1900. & No. 7 \\
\hline
\end{tabular}

\section{A FOREIGN SOVEREIGN IN AN AMERICAN COURT; A NOVEL CASE IN INTERNATIONAL PRACTICE.}

A suit was instituted in July, 1899 , in the Supreme Court of the State of New York by a citizen of that State against the Republic of Mexico, which has raised some novel questions in international law and practice. The plaintiff's suit was based upon an alleged debt of $\$ 3,075,000$, with interest at seven per cent from September $x, 1865$, represented by certain bonds said to have been issued by the Republic of Mexico. Upon the filing of the necessary papers, service was sought to be made upon the President of the Republic in the City of Mexico, and a warrant of attachment was served upon J. P. Morgan \& Co., bankers, in the City of New York, as the alleged holders of funds belonging to the defendant.

The Mexican Ambassador in Washington, under instructions from his Government, sent an official note to the Secretary of State, setting forth that the proceedings of the Supreme Court of New York were unauthorized, null, and an offense against the independence and sovereignty of the Republic of Mexico; in the name of his Government he protested against the proceedings and all the effects resulting therefrom; and asked that the Executive of the United States would take such measures as to it should seem fit for the annulment and revocation of the decrees of the Court and to cause it to renounce its claim of jurisdiction over the Mexican Government.

It appeared that no precedent existed in the Department of State indicating the course of action, if any, which the Execuve branch of the Government should take under the circum- 
stances, but a copy of the note of the Ambassador was sent by the Secretary of State to the Attorney General for his information and such action as he might deem proper. Attorney General Griggs at once recognized the principle of international law, that a sovereign state cannot be sued in a foreign jurisdiction. He regarded it as competent for the Mexican Government to appear by counsel for the sole purpose of directing the attention of the Court to its want of jurisdiction, without prejudice; but he further held that in such a plain case as the present, Mexico should not be expected to take a step which might be regarded as inconsistent with her dignity and independence, and that, under the comity of nations, the Executive department of the Government, which is charged with conducting intercourse with foreign countries, should itself appear in Court and bring about the dismissal of the proceedings.

In accordance, therefore, with the instructions of the Attorney General, Hon. Henry L. Burnett, U. S. Attorney for the Southern District of New York, appeared before the Supreme Court of New York in the City of New York, on October 9, I 899 , and filed a motion to dismiss the complaint and vacate the attachment. His right to appear under instructions from the Attorney General for the purpose of the motion, as amicus curiae, and not appearing for the defendant, was contested by the plaintiff's attorney, but recognized by the Court for reasons set forth in the opinion of the Justice hereafter given. The District Attorney supported his motion by an able brief with citation of numerous authorities, some of which appear in the opinion of the Court. The leading American case is that of the schooner Exchange v. McFadden, 7 Cranch 7 16 ,decided by Chief Justice Marshall; and that of the British Courts, the Parlement Belge, English Law Reports, 5 Probate Division 197. After oral argument by the District Attorney and by the plaintiff's attorney, the opinion of the Court was given, November 13, I899, as follows :

$$
\left.\begin{array}{c}
\text { "John G. Hassard } \\
\text { v. } \\
\text { States of Mexico et al. }
\end{array}\right\}
$$

$$
\text { Bookstaver, } J \text {. }
$$

This motion is made by the United States Attorney for the Southern District of New York, under instructions from the Attorney General of the United States, to vacate an attachment obtained by the plaintiff against the defendants and to dismiss the complaint upon the ground that this Court has no jurisdic- 
tion of the subject matter. The action is against the Republic of Mexico and States of Tamaulipas and San Luis Potosi, the latter two being subordinate divisions of the former. The amount claimed is $\$ 3,075,000$, with interest at seven per cent from September $\mathrm{x}, \mathrm{1865}$, which is alleged to be the sum due upon 3,075 bonds of the amount of $\$ 1,000$ each, issued by the defendants on or about July 4, I865.

The United States Attorney disclaims appearing by any authority from the defendants, but only on instructions from the Attorney General and as amicus curiae to call the attention of the Court to its want of jurisdiction in the premises.

That the Court is without jurisdiction seems to be a proposition beyond serious dispute. The principal defendant is an independent sovereign nation having treaty relations with this country, and the other defendants are subordinate divisions thereof.

It is an axiom of international law, of long established and general recognition, that a sovereign state cannot be sued in its own courts or in any other, without its consent and permission. For applications of this doctrine see The Exchange v. McFad- den et al., 7 Cranch 716; Manning v. State of Nicaragua, 14 How. Practice 517 ; Beers v. State of Arkansas, 20 How. 527.

This principle extends so far that a sovereign state by coming into court as a suitor does not thereby abandon its sovereignty and subjects itself to an affirmative counterclaim. People v. Dennison, 84 N. Y. 272 ; United States v. Eckford, 6 Wall 490.

So far as this doctrine is applied to foreign powers, it is obviously based upon sound considerations of international comity and peace; and it is significant that this country is so solicitous on this point that it has, by its Constitution, Article 3 , Section 3 , subdivision 2, conferred upon its highest judicial tribunal, original jurisdiction in all cases affecting ambassadors or other public ministers and consuls, and by section 667 of the United States Revised Statutes that jurisdiction is made exclusive and is extended even to domestics or domestic servants of such foreign representatives. That state courts scrupulously recognize their own lack of jurisdiction is illustrated in Valerino v. Thompson, 7 N. Y. 576 , where it was held that the exemption was a privilege not of the representative, but of his sovereign, and that he could not waive it. It was also stated that the court will put a stop to the proceedings at any stage on its being shown that they have no jurisdiction. 
So far as jurisdiction is concerned, there is no difference between suits against a sovereign directly and suits against its property. Stanley v. Schwalby, 147 U. S. 508; Unted States v. Lee, $106 \mathrm{Ib}$. 196.

The plaintiff's attorney strenuously combats the right of the District Attorney to intervene and points out that Section 682 of the Code provides expressly the only methods by which a motion to vacate an attachment can be made, and that the District Attorney has no standing under these provisions. The fault of this argument lies in the fact that Section 682 makes no provision for vacating an attachment of this kind, because the legislators never contemplated the issuance of such an attachment. Properly speaking, this is not a proceeding to vacate a thing that ever had validity, but rather to revoke what was the result of an inadvertence in an ex parte proceeding and a nullity $a b$ initio, and to set the Court right on its own records and in the eyes of the world. The motion should be granted."

The case was appealed by the plaintiff to the Supreme Court of New York in full bench, and after argument by plaintiff's attorney and the District Attorney, on the 21st of December, 1899, the order of November $13^{\text {th }}$, dismissing the complaint and vacating the warrant of attachment, was affirmed with costs. A similar suit by another plaintiff was likewise dismissed for the same reasons.

. The novel features of the foregoing case were: first, suit was brought against a Sovereign Government, directly, not by a proceeding in rem as in the leading cases cited, and notice was sought to be had by service on the foreign government; second, it is the first instance where the intervention of the Federal Executive was invoked and granted, under the comity of nations; and, third, the right of the Attorney General to appear as amicus curiae was recognized by the Court. The Foreign Diplomatic Representatives in Washington will recognize in this prompt action of the Attorney General a fresh evidence of the desire of the Executive of the United States to protect their Governments from annoyance through the inconsiderate or ignorant action of state courts.

JoHN W. Foster. 